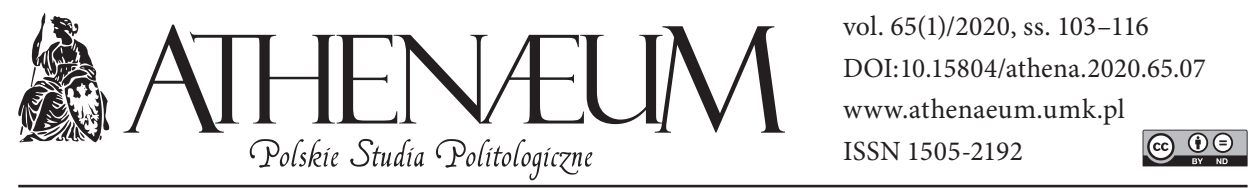

\title{
UDZIAŁ HISZPANII W MISJACH BEZPIECZEŃSTWA W SAHELU ZACHODNIM
}

\author{
SPANISH PARTICIPATION IN THE SECURITY MISSIONS \\ IN THE WEST AFRICAN SAHEL
}

Stanisław Kosmynka*

\begin{abstract}
ABSTRAKT
Artykuł prezentuje uwarunkowania strategii bezpieczeństwa Hiszpanii wobec Sahelu Zachodniego, szczególnie Mali, Mauretanii i Nigru. Przedstawia przesłanki oraz charakter realizacji hiszpańskich misji wojskowo-szkoleniowych i policyjnych w tym regionie Afryki. Rozważania zawarte w analizie wskazują na transnarodowy aspekt zagrożeń płynących ze strony ekstremizmu dżihadystycznego, pozostającego tak często w symbiozie ze zorganizowaną przestępczością, czerpiącą profity z nielegalnej migracji, handlu bronią i substancjami psychoaktywnymi. Zależności te są widoczne $\mathrm{w}$ odniesieniu do wielu państw afrykańskich, m.in. obszaru Sahelu. Artykuł podejmuje refleksję nad znaczeniem sytuacji tego regionu dla bezpieczeństwa południowej flanki Unii Europejskiej, a zarazem wyszczególnia przedsięwzięcia i projekty tam realizowane przez państwa Europy Południowo-Zachodniej (Hiszpanię, Francję i Włochy).
\end{abstract}

Słowa kluczowe: Hiszpania; Sahel; bezpieczeństwo; antyterroryzm; przestępczość
The paper shows the mechanisms and character of the Spanish security and counter-terrorism strategy towards the West African Sahel, especially Mali, Mauritania, and Niger. The article refers to the Spanish military and training missions and participation in this African region. It explains their main purposes and conditions. The paper is focused on the transnational challenges created by the jihadi extremism that in many cases presents the symbiotic relationship with organized criminal groups. The West African Sahel exemplifies this phenomenon and its impact on the European security is very important. The article explores the interface of jihadi terrorism with the criminal groups activity, especially with the drug and human trafficking. It examines main EU security projects for this African region realized by Spain, France, and Italy.

Keywords: Spain; Sahel; security; counterterrorism; criminality

* Uniwersytet Łódzki, Wydział Studiów Międzynarodowych i Politologicznych. 


\section{WPROWADZENIE}

Jedną z istotnych płaszczyzn hiszpańskiej polityki zagranicznej w dziedzinie bezpieczeństwa jest od lat trwające zaangażowanie w operacjach na rzecz niwelowania zagrożeń asymetrycznych i prowadzenia misji stabilizacyjnych, realizowanych poza obszarem Półwyspu Iberyjskiego. Najbardziej znanym tego przykładem była partycypacja Hiszpanii w interwencjach w Afganistanie oraz Iraku w ramach międzynarodowej walki z terroryzmem. O zaangażowaniu tym świadczy też udział Hiszpanii w koalicji walczącej z tzw. Państwem Islamskim - w 2014 r. zdecydowano o skierowaniu do Iraku kontyngentu składającego się z ok. 300 hiszpańskich wojskowych w celu realizacji zadań szkoleniowych dla irackiej armii (García-Calvo, 2014). W ostatnich latach ważnym elementem tej sfery polityki stała się z kolei obecność hiszpańskich misji wojskowych i policyjnych w Afryce, w regionie Sahelu - w Mali, Mauretanii i Nigrze, realizowanych pod auspicjami Ministerstw Obrony i Spraw Wewnętrznych. Operacje te stanowią istotny komponent wielopłaszczyznowej strategii zapobiegania zagrożeniom terrorystycznym, które, jak wiadomo, od lat są udziałem Hiszpanii i innych państw Starego Kontynentu, szczególnie Europy Zachodniej i Południowej.

Ekstremizm dżihadystyczny stał się w XXI wieku jednym z poważnych zagrożeń dla bezpieczeństwa Hiszpanii, o czym świadczą nie tylko przeprowadzone na terenie tego państwa zamachy terrorystyczne (Madryt 2004 r., Barcelona 2017 r.), ale również znaczna liczba komórek radykalnego salafizmu, wykrytych tam i dezaktywowanych na przestrzeni ostatnich kilkunastu lat. Aktualność i ewolucja tych zagrożeń to czynniki skłaniające władze Hiszpanii do wdrażania i rozwijania kompleksowych strategii prewencyjnych przede wszystkim na płaszczyźnie krajowej, których celem jest minimalizowanie ryzyka zamachu (Kosmynka, 2017). W ciągu minionych lat kolejne rządy tego państwa wiele uczyniły w tym zakresie: podjęły kroki służące efektywności koordynacji poszczególnych służb i pionów operacyjnych oraz instytucji odpowiedzialnych za stan bezpieczeństwa kraju, a także zainicjowały kompleksowe programy zapobiegania radykalizacji muzułmanów mieszkających na obszarze Półwyspu Iberyjskiego.

Drugim ważnym aspektem hiszpańskiej polityki bezpieczeństwa jest, jak wspomniano, współpraca międzynarodowa w zakresie walki z terroryzmem. Jest ona budowana od szeregu lat i bazuje na trzech głównych filarach: europejskim (w ramach priorytetów określonych w tym zakresie przez Unię Europejską), transatlantyckim oraz afrykańskim, obejmującym południową flankę UE i realizowanym przede wszystkim w ramach antyterrorystycznej współpracy 
z władzami Maroka. W obrębie tego trzeciego filaru sytuuje się także udział Hiszpanii w misjach realizowanych w regionie Sahelu Zachodniego - jak wiadomo regionie dość odległym geograficznie od Półwyspu Iberyjskiego, którego sytuacja wewnętrzna rzutuje jednak pośrednio na stan bezpieczeństwa Hiszpanii i państw południowo-zachodniej części Europy. Ten obszar kontynentu afrykańskiego bywa określany jako „pas transmisyjny”, łączący basen Morza Śródziemnego z Afryką Subsaharyjską (Venturi, 2017). W orbicie zainteresowania dyplomacji Madrytu sytuuje się w tym zakresie zwłaszcza obszar atlantycki Sahelu (Mauretania i Senegal) jako teren sąsiadujący z mającym istotne znaczenie dla bezpieczeństwa Hiszpanii Marokiem, jak również Mali i Niger - zajmujące strategiczne położenie pomiędzy Afryką Subsaharyjską i Północną. Wart odnotowania pozostaje też fakt, że wzrost zagrożeń ze strony terroryzmu dżihadystycznego w niektórych częściach Sahelu - np. na północy Mali - wskazywany był w analizach eksperckich jako ściśle skorelowany z zagrożeniami dla bezpieczeństwa Hiszpanii (Reinares, García-Calvo, 2013).

Celem artykułu jest ukazanie przesłanek zaangażowania Hiszpanii na obszarze Sahelu Zachodniego w kontekście działań służących poprawie bezpieczeństwa tej części Afryki, w tym szczególnie zapobieganiu zagrożeniom terrorystycznym i powstrzymaniu nielegalnej migracji. Rozważania tu zawarte dotyczą transnarodowego charakteru ekstremizmu dżihadystycznego, pozostającego tak często w relacji symbiotycznej z grupami drobnej i zorganizowanej przestępczości, czerpiącej profity z dysfunkcjonalności państwa. Region Sahelu stanowi egzemplifikację tych zależności, od dawną będąc przestrzenią aktywności nurtów radykalnych, inspirowanych ideologią walczącego salafizmu. Stąd też asymetryczne wyzwania dla stabilności regionu należy postrzegać w sposób komplementarny, obejmujący siatki kryminalne i ruchy wywrotowe, które uosabia dżihadyzm. Artykuł podejmuje refleksję nad kierunkami inicjatyw międzynarodowych, wychodzących naprzeciw tym wyzwaniom. W polskojęzycznej literaturze naukowej praktycznie nieobecne są pozycje analizujące wątek hiszpańskiej polityki bezpieczeństwa wobec regionu Sahelu. Problematyka ta pojawia się w artykułach naukowych autorów hiszpańskich: Fernando Reinaresa, Caroli Garcíi-Calvo, Sergio Altuny Galana, Beatriz Mesy.

Metodologia badań nad terroryzmem implikuje konieczność doboru interdyscyplinarnego wachlarza metod (Bolechów, 2012). W analizie przesłanek i kształtu hiszpańskiego zaangażowania w Sahelu Zachodnim pomocna jest integracja metody historycznej - szczególnie w kontekście uchwycenia relacji przyczynowo-skutkowych krystalizacji określonych mechanizmów - oraz 
systemowej, pozwalającej na ujęcie omawianych zagadnień jako powiązanego zespołu elementów, w ramach którego uwaga skupia się zarówno na ich częściach składowych, jak i wzajemnych korelacjach. W badaniu procesu przeobrażeń współczesnego terroryzmu, inspirowanego radykalnym salafizmem, ważne miejsce zajmuje wpisująca się w wymiar ruchów społecznych teoria sieci, które to pojęcie nawiązuje do prac Marca Sagemana. Autor ten ujmuje komórki dżihadystyczne jako swoisty ruch społeczny, złożony z licznych nieformalnych sieci inspirujących do terroryzmu, jak i formę organizacji (Sageman, 2008). Koncepcja ta pomaga zrozumieć złożone trajektorie radykalizacji; te z kolei implikują określony charakter środków zapobiegawczych, po które sięgać muszą na poziomie decyzyjnym władze, oraz wykonawczym - odpowiednie organy i służby państw, zarówno krajowe, jak i międzynarodowe.

\section{ZAANGAŻOWANIE HISZPANII W REGIONIE SAHELU ZACHODNIEGO}

Obecność Sahelu Zachodniego (przede wszystkim Mali, Mauretanii i Nigru) w sferze hiszpańskiej polityki zagranicznej to fakt stosunkowo nowy; jest wypadkową problemów społecznych dotykających tę część Afryki, których konsekwencje stały się udziałem Europy Zachodniej i Południowej. Jak ważną rolę pełni Zachodni Sahel z perspektywy migracji do Hiszpanii, unaoczniła władzom tego państwa sytuacja w lecie 2016 r., kiedy to 31.700 osób, pochodzących głównie z Senegalu i Mauretanii, przybyło nieoczekiwanie na Wyspy Kanaryjskie. Wydarzenie to zintensyfikowało współpracę Hiszpanii z państwami Afryki Zachodniej, które to kroki zaowocowały powstrzymaniem napływu imigrantów na Wyspy Kanaryjskie (González Enríquez, Lisa, Selin Okyay, Palm, 2018). Kryzys migracyjny, działalność zorganizowanych grup przestępczych czerpiących korzyści $\mathrm{z}$ handlu ludźmi, obrotu substancjami psychoaktywnymi, przemytu broni oraz krystalizacja siatek dżihadystycznych na terenie Sahelu oraz Maghrebu stały się czynnikami rzutującymi na bezpieczeństwo państw europejskich, przede wszystkim, jak zaznaczono, w basenie Morza Śródziemnego. Władze Hiszpanii mają świadomość tych zależności oraz ich wagi dla sytuacji wewnętrznej kraju, stąd też, pomimo wcześniejszych animozji politycznych, rozwinęły współpracę w zakresie bezpieczeństwa z południowym sąsiadem - Marokiem. Podjęły też działania mające na celu normalizację sytuacji politycznej i ekonomicznej w innych państwach, doświadczających aktywizacji siatek przestępczych i nur- 
tów integrystycznych, których rozwojowi od dawna sprzyjają niestabilność polityczna, niedostatki instytucjonalne, a zarazem wysokie wskaźniki ubóstwa i wykluczenia społecznego.

W 2009 r. troje hiszpańskich obywateli, członków misji humanitarnej, zostało uprowadzonych w Mauretanii i wywiezionych na teren Mali. Sprawcami porwania byli członkowie powiązanej z Al-Kaidą Muzułmańskiego Maghrebu (AQIM), bojówki dżihadystycznej. Wydarzenie to doprowadziło do intensyfikacji kontaktów rządu w Madrycie z władzami państw regionu: Mali, Mauretanii, Burkiny Faso, a także - w konsekwencji - do uwrażliwienia na pośredni charakter zagrożeń dla bezpieczeństwa Hiszpanii, wynikających z sytuacji w Sahelu Zachodnim (Mesa, 2017). Porwania cudzoziemców stały się zresztą w regionie Zachodniego Sahelu znamiennym dla dżihadytstów modus operandi - doskonale wpisywały się w kontekst ideologiczny nurtów radykalnych, a zarazem oferowały ich przedstawicielom szansę na lukratywny dochód. Tak np. w lutym 2008 r. porwano w Tunezji parę Austriaków, którzy następnie zostali przewiezieni do Mali. W grudniu 2008 r. również na terenie Mali uprowadzeni zostali dwaj Kanadyjczycy, a niespełna rok później obywatel Francji. W 2009 r. w Nigrze porwano Brytyjczyka (wskutek niespełnienia żądań porywaczy został zamordowany) oraz dwóch Włochów. We wrześniu 2010 r. w Nigrze uprowadzono pięcioro Francuzów, w styczniu 2011 r. - kolejnych dwóch. Podobnych aktów przemocy było więcej. W wielu przypadkach za uwolnienie swych obywateli władze państw europejskich wypłaciły porywaczom wielomilionowy okup (Izak, 2016).

Obok Al-Kaidy Muzułmańskiego Maghrebu w ostatnich latach pojawiły się też inne, pochodne ugrupowania fundamentalistyczne i przestępcze, będące często odgałęzieniami AQIM, takie jak powstały w 2011 r. Ruch na Rzecz Jedności i Dżihadu w Afryce Zachodniej (MUJAO), który dwa lata później wszedł w skład organizacji Al-Murabitun, czy założony w 2012 r. w Mali Ansar ad-Din. Wszystkie one miały charakter antysystemowy, głosiły ideę „świętej wojny”, a jednocześnie uwikłane były w działalność kryminalną. Wielu spośród członków ugrupowań ekstremistycznych rekrutowało się ze społeczności Tuaregów z Nigru oraz Mali i deklarowało lojalność AQIM, a potem tzw. Państwu Islamskiemu. Niepokoją zarazem doniesienia, że komórki afiliujące się do AQIM pojawiły się na terenie Burkina Faso (Jama’a Nusrat ul-Islam wa al-Muslimin) (Zenn, 2018).

Rozważając powyższe kwestie, należy zarazem mieć świadomość istnienia uwarunkowań endogennych, rzutujących na złożoność sytuacji w tej części Afryki i multiplikujących wyzwania dla bezpieczeństwa. Określa je struktura plemienna społeczeństw regionu, których wzajemne interakcje mają nierzadko 
charakter antagonistyczny. Obok ugrupowań spajanych ideologią walczącego salafizmu nie można zapominać o istnieniu szeregu konfliktów wewnętrznych i o działających na tym tle nurtach secesjonistycznych Tuaregów, np. w Azawadzie na północy Mali, oraz aktywności licznych grup przestępczych, co niewątpliwie pogłębia destabilizację regionu. Warto zarazem pamiętać, że na sytuację taką od lat oddziałują również chaos i dysfunkcyjność Libii po upadku reżimu Al-Kaddafiego (Cristiani, 2011). Konflikt wewnętrzny w tym państwie okazał się być czynnikiem sprzyjającym aktywizacji komórek dżihadystycznych autoafiliujących się do tzw. Państwa Islamskiego. Na obszar Sahelu trafiła z terenu Libii duża część broni i sprzętu wojskowego. Wewnętrzna niestabilność zaktywizowała też organizacje przestępcze czerpiące zyski z handlu narkotykami: „Narkobiznes został uwolniony od mechanizmów zapobiegawczych ustanowionych przez Kaddafiego. Do Nigru przyjeżdżały z Mali samochody wypełnione haszyszem i kierowały się ku płaskowyżowi Dżado w północno-wschodniej części kraju, przy granicy z Libią i Czadem, a następnie wracały z ładunkiem broni” (Izak, 2016). Sytuacja taka wykreowała bardzo dogodne warunki dla rozwoju nurtów wywrotowych, opowiadających się za ideologią radykalnego salafizmu, który dla wielu z nich stanowił przede wszystkim czynnik legitymizujący uprawianie procederu przestępczego. Stąd też niepozbawione zasadności są opinie, że komponent ideologiczny jest niejako czynnikiem wtórnym, legitymizującym działalność kryminalną oraz przynoszącym konkretne profity: Beatriz Mesa używa w tym kontekście znamiennego określenia „fałszywy dzihad” (Mesa, 2017).

Polityki Hiszpanii w regionie Sahelu nie determinują jedynie kwestie bezpieczeństwa - choć zajmują one miejsce priorytetowe - ale ma ona także wymiar społeczno-ekonomiczny. W ostatnich latach wyraźnie wzrosła skala hiszpańskich inwestycji w porozumieniu z partnerami należącymi do Wspólnoty Gospodarczej Państw Afryki Zachodniej, obejmujących m.in. sektor infrastruktury i przedsiębiorczości. Należy jednocześnie pamiętać, że kontynent afrykański wyraźnie wpisał się w orbitę hiszpańskiej polityki zagranicznej w kontekście współczesnym w 2006 r., kiedy to rząd premiera José Luisa Rodrigueza Zapatero ogłosił realizację przewidzianego na dwa lata tzw. „Planu Afryka”, podyktowanego przesłankami wsparcia społeczno-ekonomicznego, a co za tym idzie - powstrzymania nielegalnej migracji. Celem tego projektu było m.in. ożywienie obecności Hiszpanii w różnych częściach kontynentu (otwarcie ambasad w Mali, Sudanie, na Wyspach Zielonego Przylądka oraz przedstawicielstw handlowych w Angoli, Kenii, Nigerii, Senegalu, Republice Południowej Afryki), wspieranie demokracji, pomoc we wdrażaniu i realizacji przedsięwzięć służących przeciwdziałaniu 
biedzie i wykluczeniu społecznemu, szczególnie w regionie subsaharyjskim. Zmierzenia tego planu były, jak widać, bardzo ambitne i wkrótce okazało się, że znacznie przekraczają przewidziane na ich realizację środki w budżecie (Alberdi Bidaguren, Bidaurratzaga Aurze, 2010).

Poczynając od 2006 r., Hiszpania zawarła porozumienia dotyczące współpracy w zakresie monitoringu wód terytorialnych Wysp Zielonego Przylądka, Gwinei Bissau, Mali, Senegalu, Mauretanii i Gambii, a co za tym idzie - strategii neutralizacji funkcjonujących tam siatek przestępczych. Szybko stało się jasne, że dysfunkcjonalność wielu regionów Afryki sprzyja krystalizacji wyzwań mających charakter regionalny oraz że bez zaangażowania partnerów zagranicznych eskalacja wewnętrznych trudności stanie się faktem, z którym nie są w stanie skutecznie zmierzyć się władze lokalne.

Aktywizacja w 2012 i 2013 r. grup dżihadystycznych na obszarze Mali, powiązanych $\mathrm{z}$ działającymi na terenie Maghrebu komórkami Al-Kaidy, zwróciła uwagę środowisk międzynarodowych na tę część Afryki. Wyrazem zaniepokojenia UE sytuacją w regionie była, zapoczątkowana w styczniu 2013 r., francuska operacja w Mali pod kryptonimem „Serwal”, w której udział wzięły również jednostki pochodzące $\mathrm{z}$ innych państw, $\mathrm{w}$ tym także $\mathrm{z}$ Hiszpanii (od kwietnia 2013 r. rozpoczęła się też misja pokojowa ONZ). Warto dodać, że celem jednostek hiszpańskich nie było prowadzenie działań ofensywnych, ale wsparcie dla lokalnych władz, o czym mowa dalej. W czerwcu 2013 r. rząd w Madrycie podjął decyzję o powiększeniu hiszpańskiego kontyngentu wojskowego, biorącego udział w operacji w tym kraju, do liczby 110 żołnierzy (Kosmynka, 2015). W 2018 r. liczył on już ok. 290 osób (Araluce, 2018), a więc został dość znacznie wzmocniony, co także świadczy o strategicznym dla Hiszpanii znaczeniu walki $\mathrm{z}$ dżihadyzmem w Sahelu. Przedsięwzięcie to było zainicjowane w ramach projektu European Union Training Mission in Mali (EUTM Mali) i podyktowane przesłanką stabilizacji regionu oraz uniemożliwienia rozprzestrzeniania się aktywności nurtów dżihadystycznych. Misja obejmowała współpracę z siłami porządkowymi Mali: szkolenia, instruktaż, doradztwo wojskowe, patrole, pomoc w ochronie infrastruktury itp. Szacuje się, że w ramach programu EUTM do 2018 r. przeszkolono ok. 11,5 tys. malijskich żołnierzy, głównie w zakresie zadań operacyjnych, wymierzonych w ugrupowania radykalnie salafickie oraz siatki przestępcze (EUTM-Mali. Misión..., 2019).

Pomimo tych starań na terenie Mali nadal widoczna jest obecność ugrupowań dżihadystycznych; szacuje się, że w latach 2016-2018 zamordowały one aż ok. 1200 osób (Sánchez agradece a las tropas..., 2018). Na początku 2019 r. 
śmierć poniosło kilku żołnierzy ONZ, należących do kontyngentu stacjonującego w Mali. Wyraźnie widoczne jest niebezpieczeństwo generowane przez nurty integrystyczne. W operacji na terenie Sahelu wziął udział hiszpański powietrzny kontyngent wojskowy o nazwie „Kość słoniowa”, prowadzący misje logistyczne i zaopatrzeniowe nie tylko na obszarze Mali, ale również Senegalu, Nigru, Mauretanii, Burkina Faso i Czadu. Pomimo niemałych wydatków, które towarzyszyły tym przedsięwzięciom - tak np. w 2016 r. operacja w Mali kosztowała ok. 89,2 mln euro, utrzymanie zaś jednostki powietrznej w Senegalu oznaczało wydatek ok. 27,6 mln euro (Araluce, 2016) - priorytetowe znaczenie kwestii bezpieczeństwa okazało się czynnikiem przesądzającym o zasadności kontynuowania tych projektów.

U schyłku 2018 r. premier Hiszpanii Pedro Sánchez wyraził wdzięczność biorącym udział w operacji w Mali żołnierzom, przypisując jej znaczenie strategiczne z perspektywy bezpieczeństwa kraju i Unii Europejskiej. Ogółem w maju 2018 r. w hiszpańskich misjach, realizowanych w Afryce w ramach UE i NATO, wzięło udział ponad czterystu wojskowych (Misiones en el exterior, 2018). Oprócz Sahelu jednostki hiszpańskie uczestniczyły w przedsięwzięciach także w innych częściach kontynentu - Republice Środkowoafrykańskiej i Somalii. Działaniom tym od kilku lat towarzyszą kontakty dwustronne na szczeblu politycznym, poświęcone kwestiom bezpieczeństwa - jednym z nich było mające miejsce w Mauretanii w listopadzie 2014 r. spotkanie hiszpańskiego ministra obrony Pedro Morenesa $\mathrm{z}$ władzami tego afrykańskiego państwa, poświęcone określeniu kierunków wspólnych inicjatyw w walce z ekstremizmem dżihadystycznym.

Hiszpańskie zaangażowanie na rzecz bezpieczeństwa w Sahelu Zachodnim egzemplifikuje udział Madrytu w przyjętym w czerwcu 2016 r. przez Komisję Europejską projekcie GAR-SI Sahel (Rapid Action Groups - Monitoring and Intervention in the Sahel). Inicjatywa ta obejmowała sformowanie sześciu Jednostek Szybkiego Reagowania, liczących od 100 do 120 osób, w państwach regionu (Mauretania, Mali, Niger, Burkina Faso, Czad i Senegal), przeszkolonych i wyposażonych dzięki wsparciu partnerów europejskich. Kierownictwo projektu powierzone zostało stronie hiszpańskiej (formacji paramilitarnej - Guardia Civil); udział w nim wzięły także francuska żandarmeria, włoski Korpus Karabinierów oraz portugalska Gwardia Narodowa, a więc pochodzące z państw, dla których stabilność południowej flanki UE stanowi jeden z ważnych filarów bezpieczeństwa. Głównym celem projektu było udoskonalenie mechanizmów kontroli obszarów należących do wyżej wspomnianych krajów, a co za tym idzie - walka z terroryzmem i przestępczością zorganizowaną, szczególnie na 
obszarach przygranicznych. Budżet tej zaplanowanej na dwa lata inicjatywy od marca 2017 r. obejmował ok. 42 mln euro pochodzących z Nadzwyczajnego Funduszu Powierniczego UE na rzecz Afryki (Altuna Galán, 2018). Poczynaniom tego rodzaju towarzyszą inne kompleksowe projekty, mające na celu poprawę sytuacji w regionie; tak np. w samym tylko $2017 \mathrm{r}$. w ramach pomocy humanitarnej dla Sahelu UE przeznaczyła środki w wysokości $234 \mathrm{mln}$ euro (Lebovich, 2018). Warto zauważyć, że Unia Europejska zdaje się dostrzegać szczególną rolę Hiszpanii w tej części Afryki; w 2015 r. przedstawiciel tego kraju, Ángel Losada, został powołany na stanowisko Specjalnego Wysłannika UE w Sahelu, do czego niewątpliwie przyczyniła się efektywna polityka migracyjna Hiszpanii w kontekście powstrzymania nielegalnego napływu obywateli Afryki na Wyspy Kanaryjskie.

Zarazem nie należy zapominać, że hiszpańskie kontakty w dziedzinie bezpieczeństwa z partnerami z Sahelu miały miejsce już kilka lat wcześniej. $\mathrm{Na}$ podstawie porozumienia o współpracy, zawartego z rządem Senegalu we wrześniu 2006 r. (FRONTEX Programme), strona hiszpańska przekazała temu państwu m.in. łodzie patrolowe i helikopter, a także wysłała tam grupy doradczą i szkoleniową. Rozpoczęto także wspólne patrole hiszpańskiej i senegalskiej żandarmerii (González Enríquez, Lisa, Selin Okyay, Palm, 2018). Umowy o współpracy o podobnym charakterze zawierano też w latach kolejnych, np. w 2009 r. W 2012 powstała w tym państwie jednostka sił specjalnych, do czego przyczyniła się współpraca hiszpańskiej i senegalskiej żandarmerii. Z biegiem czasu, w sytuacji coraz wyraźniejszej krystalizacji zagrożeń dla bezpieczeństwa o charakterze transnarodowym, zarysowała się potrzeba implementowania kompleksowych rozwiązań regionalnych, których efektywność - z uwagi na niedostatki instytucjonalne, powszechną korupcję, brak należytych środków oraz inne trudności wewnętrzne i problemy strukturalne państw Sahelu - uzależniona jest w tak dużym zakresie od wsparcia zagranicznego. O konieczności wdrażania zintegrowanych rozwiązań świadczy np. sytuacja na pograniczu Nigru i Czadu, będącym teatrem aktywności działającej w różnych państwach afrykańskich organizacji islamistycznej Boko Haram (Zenn, 2017, Country Reports of Terrorism 2016,2017), czy położona na terenie Nigru i sąsiadująca z Mali i Burkina Faso trójgraniczna strefa Tillabéri - gdzie uwidoczniła się aktywność grup dżihadystycznych deklarujących w minionych latach lojalność wobec tzw. Państwa Islamskiego.

Warto zauważyć, że wybór Hiszpanii jako państwa przewodniczącego projektowi GAR-SI Sahel i mu patronującego jest nieprzypadkowy. Jej doświadczenia 
$\mathrm{w}$ walce $\mathrm{z}$ terroryzmem są bogate i nie wyznaczają ich jedynie zmagania $\mathrm{z}$ ekstremizmem salafickim, lecz także, jak wiadomo, wieloletnie zagrożenia płynące ze strony terroryzmu separatystycznego baskijskiej organizacji ETA. W 1978 r. powołana została w Kraju Basków Jednostka Szybkiego Reagowania (GAR Grupo de Acción Rápida), której głównym celem było zwalczanie ETA. W tym kontekście struktura i doświadczenia tej formacji okazały się nader przydatne do opracowania projektu GAR-SI Sahel. GAR w ostatnich latach realizuje zadania, które implikują zagrożenia wynikające z terroryzmu dżihadystycznego na terenie Hiszpanii i poza jej granicami - uczestniczyła w misjach w Afganistanie oraz w Afryce (w Nigrze, Czadzie i Mauretanii).

GAR-SI Sahel to niejedyne przedsięwzięcia tego typu, w których zaznaczyła swoją obecność strona hiszpańska. Na przestrzeni ostatnich lat współpraca Madrytu z państwami Afryki Zachodniej (głównie z Mauretanią, ale również z Marokiem, Mali, Senegalem, Wyspami Zielonego Przylądka) zaowocowała realizacją szeregu projektów, których celem była poprawa bezpieczeństwa regionu (Altuna Galán, 2018). Oto niektóre z nich:

- Seahorse, 2006-2008;

- Seahorse Network, 2008-2009;

- Seahorse Coordination Centres, 2009 - 2010;

- West Sahel, 2011-2013;

- West Sahel II, 2014-2016;

- Blue Sahel, 2017-2019.

Działania realizowane w ramach tych inicjatyw obejmowały m.in. poprawę efektywności mechanizmów kontroli obszarów przygranicznych (wspólne patrole), koordynację działań poszczególnych pionów decyzyjnych, organów operacyjnych i wywiadowczych, szkolenie służb porządkowych, skuteczniejszą ochronę infrastruktury, przeciwdziałanie przemytowi dóbr, handlowi substancjami psychoaktywnymi oraz bronią.

Walka z przestępczością zorganizowaną, czerpiącą profity z handlu ludźmi i nielegalnych migracji, stała się zarazem główną przesłanką powołania w Nigrze wspólnego pionu śledczego, obejmującego przedstawicieli policji tegoż państwa oraz partnerów hiszpańskich i francuskich (Altuna Galán, 2018). Już w 2012 r. zainicjowana została $\mathrm{z}$ ramienia UE misja szkoleniowa w tym afrykańskim państwie, której celem było przygotowanie lokalnych służb do akcji antyterrorystycznych. Kierownikiem tej misji został oficer hiszpańskiej żandarmerii, płk Francisco Espinosa Navas. W przedsięwzięciu tym wzięli udział również doradcy i eksperci pochodzący z Francji, Belgii, Włoch i Szwecji. Współpraca z władzami 
Nigru była kontynuowana w kolejnych latach. W marcu 2017 r. w stolicy tego państwa, Niamej, miało miejsce spotkanie ministrów spraw wewnętrznych Hiszpanii, Francji i Nigru, podczas którego zapowiedziano zacieśnienie współpracy $\mathrm{w}$ walce $\mathrm{z}$ terroryzmem i przestępczością zorganizowaną $\mathrm{w}$ ramach inicjatyw dwustronnych oraz przy wykorzystaniu środków UE. Przypadek rozwoju komórek dżihadystycznych w Nigrze świadczy m.in. o tak akcentowanym w tej analizie znaczeniu kontroli obszarów przygranicznych, będących strefami bardzo podatnymi na działalność nurtów wywrotowych - oprócz wspomnianych wyżej przykładów tendencję tę ilustruje przypadek nigryjskiego pogranicza z Libią, Algierią i Mali, gdzie niedostatecznie efektywna kontrola państwa sprzyja kryminalizacji tego obszaru. Jakkolwiek w 2016 r. odnotowano spadek liczby incydentów terrorystycznych w tym państwie, to jednak oczywiste jest, że wyzwania nadal istnieją (Global Terrorism Index, 2017). W ramach projektu EUCAP (European Union Capacity Building) przewidziano wsparcie dla wdrożenia Narodowej Strategii Bezpieczeństwa w Nigrze, jednak - z uwagi na trudności strukturalne i bariery instytucjonalne - przedsięwzięcia realizowane w ramach tego planu trudno uznać, jak na razie, za w pełni satysfakcjonujące (Strenghtening the capacity..., 2018).

\section{PODSUMOWANIE}

Reasumując, obszar Sahelu stanowi ważny strategicznie obszar z perspektywy wyzwań dla bezpieczeństwa Europy Południowej, co zresztą szczególnie wyraźnie odzwierciedla zaangażowanie innego europejskiego państwa - Francji w tym regionie. Francuskie wsparcie finansowe i wojskowe stanowi istotny filar pomocy w walce z ekstremizmem salafiskim dla tzw. grupy G5 (Mali, Burkina Faso, Czad, Niger, Mauretania), o czym świadczą m.in. przeprowadzone w 2017 r. operacje „Hawbi” i „Barkhane”. Zagrożenia dla bezpieczeństwa regionu wynikają ze swoistej konwergencji, łączącej nurty ekstremizmu dżihadystycznego z grupami przestępczymi oraz z faktów rzutujących na te procesy - związków ubóstwa i wykluczenia społecznego z uwewnętrznieniem skrajnych ideologii, dysfunkcjonalnością państwa, problemem nielegalnych migracji itp. W tym kontekście oczywisty wydaje się wniosek, że efektywność przeciwdziałania tym wyzwaniom jest zależna od skuteczności poszukiwania rozwiązań u ich źródła, nie zaś na koncentracji na osiąganiu celów krótkodystansowych (np. rozbiciu już istniejących komórek terrorystycznych). Ta zaś bazować powinna 
na skorelowaniu instrumentów prawnych i prewencyjnych oraz niwelowaniu oddziaływania idei integrystycznych w połączeniu z kompleksowymi krokami na rzecz inkluzji społecznej, wyrównywania szans, wzmacniania instytucji państwa itp. Jest to szczególnie ważne z perspektywy socjalizacji ludzi młodych, tak często kuszonych propagandą dżihadystyczną lub afiliacją do grup przestępczych, postrzeganych jako szansa na lepsze życie. Efektywność tych wysiłków w dużym stopniu jest uzależniona od długofalowego wsparcia zagranicznego dla państw afrykańskich, obejmującego wielopłaszczyznową współpracę międzynarodową w zakresie bezpieczeństwa, służącą poprawie koordynacji działań na poziomie krajowym i zagranicznym. Władze Hiszpanii, jak wykazano, dostrzegają potrzebę zaangażowania w przedsięwzięcia podejmowane na obszarze Sahelu w celu ograniczenia skali tych wyzwań. Ich znaczenie dobitnie określił na początku lutego 2018 r. hiszpański minister spraw zagranicznych Alfonso Dastis: „Mamy świadomość, że po klęsce tzw. Państwa Islamskiego na terenie Syrii i Iraku część jego dawnych bojowników uda się do Sahelu i Libii. Staną tym samym nieomalże u naszych granic" (Spain sounds alarm..., 2018). Podobne stanowisko zajął zresztą w 2015 r. jego poprzednik, José Manuel García-Margallo.

Jak wspomniano, polityka Hiszpanii wobec regionu Sahelu Zachodniego pozostaje zarazem ściśle związana ze strategią UE w zakresie migracji, bezpieczeństwa i niwelowania wciąż nierozwiązanych, endogennych wyzwań, znamiennych dla tego obszaru. W tym zakresie wyróżnia się szczególnie współpraca Madrytu z Paryżem oraz Rzymem, np. przewidziany na lata 2017-2020 hiszpańsko-włoski projekt PACERSEN, mający na celu inkluzję społeczności zamieszkujących wiejskie obszary Senegalu (González Enríquez, Lisa, Selin Okyay, Palm, 2018). Warto mieć także na uwadze, że przeszłość kolonialna Francji delegitymizuje jej działania w oczach wielu mieszkańców regionu, którzy postrzegają obecność tego państwa nierzadko jako wyraz realizacji neokolonialnych interesów politycznych lub ekonomicznych. Hiszpania zaś jest odbierana w tym wymiarze bardziej neutralnie, co może ułatwić jej poczynania zarówno w sferze dyplomatycznej, jak i w kontekście konkretnych operacji w terenie. Trzeba też pamiętać, że na efektywność polityki państw UE wobec Sahelu wpływa też oczywiście spójność i koherentność strategii wobec regionu - widoczne w tym kontekście na początku 2019 r. animozje polityczne między Paryżem a Rzymem mogą negatywnie wpłynąć na charakter tej współpracy.

Wpływ ewentualnej postępującej destabilizacji Sahelu na sytuację wewnętrzną Hiszpanii byłby istotny, zwłaszcza w sytuacji, gdyby obszar ten rzeczywiście stałby się schronieniem dla byłych bojowników tzw. Państwa Islamskiego. Perspektywa 
ta w dużym stopniu uzasadnia podejmowane w ostatnim czasie przez władze Hiszpanii działania w regionie (Losada Fernández, 2018). Trudno jednocześnie nie zgodzić się z Sergio Altuną Galanem, ekspertem Królewskiego Instytutu Elcano, który zauważa, że aktywność Madrytu w regionie Sahelu może mieć zarazem pośredni, niechciany efekt: zwrócenie uwagi terrorystów na Hiszpanię i dostarczenie im dodatkowych przesłanek do kształtowania narracji określającej to państwo jako wrogie i opresyjne wobec muzułmanów, a co za tym idzie multiplikowanie i tak już istniejących zagrożeń terrorystycznych dotykających ten kraj (Altuna Galán, 2018). Stąd też jednym z filarów bezpieczeństwa nadal pozostaje rozbudowa wielotorowych inicjatyw regionalnych, obejmujących wysiłki służące niwelowaniu endogennych uwarunkowań rozwoju ekstremizmu i przestępczości. Obecność Sahelu Zachodniego w orbicie hiszpańskiej polityki zagranicznej doskonale ilustruje te zależności.

\section{BiBLIOGRAFIA:}

Alberdi Bidaguren, J., Bidaurratzaga Aurre, E. (2010). El Plan África 2006-2008. Cuestiones para el debate. Instituto de Estudios de Desarrollo y Cooperación Internacional: FOROAOD - La Ayuda española al desarrollo.

Altuna Galán, S. (2018). Jama’at Nusrat al-Islam wa-l-Muslimin: análisis del proyecto de al-Qaeda para el Sahel a través de su propaganda. Real Instituto Elcano de Estudios "ARI”, 4.

Altuna Galán, S. (2018). La contribución española actual a la lucha contra el terrorismo en el Sahel. Real Instituto Elcano de Estudios Internacionales, „ARI”, 4, 8.

Araluce, G. (2018). El ejército español toma el mando para apaciguar el polvorín yihadista de Mali. El Español, 4.

Araluce, G. (2016). Ranking del coste de las misiones militares españolas en el extranjero. El Español, 7.

Bolechów, B. (2012). Polityka antyterrorystyczna w świetle badań nad terroryzmem. Wrocław: Wydawnictwo Uniwersytetu Wrocławskiego.

Country Reports on Terrorism 2016. United States Department of State Publication: Bureau of Counterterrorism, 45-47.

Cristiani, D. (2011). Missiles, Money and Migration: The Impact of the Libyan Crisis on the African Sahel. Terrorism Monitor, IX(15), 6-8.

EUTM-Mali. Misión Militar de la UE en Malí, Estado Mayor de la Defensa. Mando de Operaciones. Pobrane z: http://www.emad.mde.es/MOPS/090-Mali-EUTMMALI/.

García-Calvo, C. (2014). Los españoles ante el Estado Islámico y la coalición internacional contra el yihadismo. Real Instituto Elcano de Estudios "ARI", 1.

Global Terrorism Index, (2017). Measuring and understanding the impact of terrorism. Study of Terrorism and Responses to Terrorism. 
González Enríquez, C., Lisa, P., Selin Okyay, A., Palm, A. (2018). Italian and Spanish approaches to external migration management in the Sahel: venues for cooperation and coherence. Real Instituto Elcano Working Paper, 13(2018), 14.

Izak, K. (2016). Leksykon organizacji i ruchów islamistycznych. Dialog, 464-466.

Kosmynka, S. (2015). Święta wojna w Al-Ándalus. Przeobrażenia aktywności dżihadystycznych komórek terrorystycznych w Hiszpanii w latach 1995-2012. Łódź: Wydawnictwo Uniwersytetu Łódzkiego.

Kosmynka, S. (2017). Zapobieganie radykalizacji społeczności muzułmańskich jako element strategii antyterrorystycznej władz Hiszpanii. W: T. Domański (red.). Międzynarodowe oblicza terroryzmu (s. 166-178). Łódź: Wydawnictwo Uniwersytetu Łódzkiego.

Lebovich, A. (2018). Halting ambition: EU migration and security policy in the Sahel, European Council on Foreign Relations. Policy Brief, 266, 23.

Losada Fernández, Á. (2018). El Sahel: un enfoque geostratégico. Real Instituto Elcano de Estudios Internacionales, „ARI”, 5.

Mesa, B. (2017). El interés de España en el Sahel. Esglobal, 34.

Mesa, B. (2013). La falsa Yihad. El negocio de narcotráfico en El Sahel. Editorial Edalaya, San Fernando.

Misiones en el exterior, Ministerio de Defensa. Pobrane z: http://www.defensa.gob.es/ misiones/en_exterior/.

Reinares, F., García-Calvo, C. (2013). El norte de Mali como foco de amenaza terrorista para España: ¿nuestro patio trasero o simplemente nuestro patio? Real Instituto Elcano de Estudios Internacionales, „ARI”.

Sageman, M. (2008), Leaderless Jihad. Terror Networks in the Twenty-First Century, Philadelphia: University of Pennsylvania Press.

Sánchez agradece a las tropas españolas en Malí su labor 'estratégica' para la seguridad de España y de la UE. Pobrane z: https://www.eleconomista.es/politica/noticias/9604795/12/18/Pedro-Sanchez-viaja-por-sorpresa-a-Mali-para-felicitar-laNavidad-a-las-tropas-espanolas-.html.

Spain sounds alarm over fighter influx from Sahel. Pobrane z: https://www.dailymail. co.uk/wires/afp/article-5369283/Spain-sounds-alarm-fighter-influx-Sahel.html.

European Court of Auditors. (2018). Strenghtening the capacity of the internal security forces in Niger and Mali: only limited and slow progress, 32-33.

Venturi, B. (2017). The EU and the Sahel: A Laboratory of Experimentation for the Security-Migration-Development Nexus. Foundation for European Progressive Studies, „IAI Working Papers, 17(38), 2.

Zenn, J. (2018). Burkina Faso and the Loombing Jihadist Threat to Coastal West Africa. Terrorism Monitor, XVI(24), 5-7.

Zenn, J. (2015). Mindful of the Islamic State, Boko Haram Broadens Reach into Lake Chad Region. Terrorism Monitor, XIII(3), 8-11. 